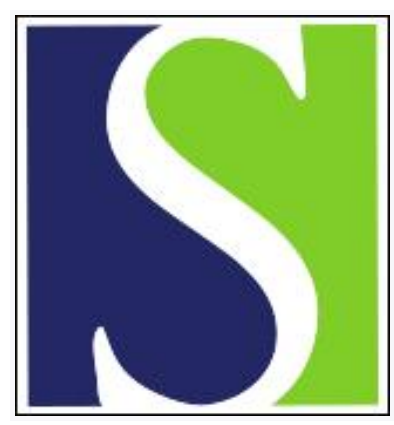

Scand J Work Environ Health 1976;2(2):96-106

https://doi.org/10.5271/sjweh.2814

Issue date: Jun 1976

Exposure to anesthetic gases and ethanol during work in operating rooms.

by Göthe C-J, Övrum P, Hallen B

Key terms: anesthetic gas; decay curve; ethanol; exposure; halothane; occupational exposure; operating room; ventilation; work

This article in PubMed: www.ncbi.nlm.nih.gov/pubmed/959795

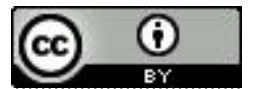




\title{
Exposure to anesthetic gases and ethanol during work in operating rooms
}

\author{
by CARL-JOHAN GÖTHE, M.D., ${ }^{1}$ PER ÖVRUM, M.Sc., ${ }^{2}$ \\ and BÖRJE HALLEN, M.D. ${ }^{3}$
}

\begin{abstract}
GÖTHE, C.-J., ÖVRUM, P. and HALLEN, B. Exposure to anesthetic gases and ethanol during work in operating rooms. Scand. $j$. work environ. \& health 2 (1976) 96-106. The concentration of halothane and ethanol in operating rooms was measured during 37 routine operations perfomed in nine different departments of surgery at six different hospitals. The time-weighted halothane concentrations in the respiratory zones of anesthetic and surgical nurses were $0.3-34.0 \mathrm{ppm}$ (time-weighted average $7.2 \mathrm{ppm}$ ) and $0.1-9.2 \mathrm{ppm}$ (time-weighted average $2.5 \mathrm{ppm}$ ), respectively, in the different operating departments. The corresponding ethanol concentrations were $0.3-36.5 \mathrm{ppm}$ (time-weighted average $12.5 \mathrm{ppm}$ ) for anesthetic nurses and 1.5-46.6 ppm (time-weighted average $15.3 \mathrm{ppm}$ ) for surgical nurses. The anesthetic technique influences the exposure of the operating staff to anesthetic gases, but it does not affect exposure to ethanol. In controlled experiments volunteers were exposed to low concentrations of halothane or ethanol. About $60 \%$ of both substances was retained. The content of ethanol in the end-expired air approached zero within a few minutes after the end of exposure, while low residual concentrations of halothane were demonstrable for more than $1 \mathrm{~h}$. Although exposure to ethanol is insignificant in relation to the metabolic capacity of the body, ethanol indicates the presence of volatile disinfectant components, and its spread through the room atmosphere should be kept in mind when the ventilation of operating rooms is designed. The effective elimination of airborne pollutants in operating rooms calls for good general ventilation in conjunction with local exhaust close to the sources of anesthetic gas leakage. General ventilation mainly affects the concentration of substances well-mixed with the room atmosphere, such as volatile disinfectant components and anesthetic vapor that has spread beyond the actual work zones of the medical staff. For a significant reduction in the concentration of anesthetic gases in the respiratory zones of the medical staff, the gases must be vented at the source of leakage. Since airborne anesthetics occur not only in operating rooms, general ventilation has to meet certain minimum requirements also in anesthetic induction rooms and recovery rooms. Operating rooms and anesthetic induction rooms must also be supplied with local exhaust systems.
\end{abstract}

Key words: halothane, ethanol, occupational exposure, ventilation, operating room, decay curve.

1 Clinic of Occupational Medicine, Södersjukhuset, Stockholm, Sweden.

2 Technology Division, Department of Occupational Medicine, National Board of Occupational Safety and Health, Stockholm, Sweden.

3 Clinic of Anesthesiology, Södersjukhuset, Stockholm, Sweden.

Reprint requests to: Dr. Carl-Johan Göthe, Clinic of Occupational Medicine, Södersjukhuset, S-100 64 Stockholm, Sweden.
The object of the present investigation was to study the manner in which the exposure of medical staffs to anesthetic gases varies with the anesthetic technique employed and the ventilation standard of the operating room. For practical reasons the study was limited to operations performed with halothane as the main anesthetic. As ethanol was consistently encountered in the air samples collected 
from operating rooms, the exposure to this substance was also studied.

The investigation is part of a larger project including studies of the ventilation in operating rooms (47), studies of the effect of anesthetic gases on the psychomotor functions of anesthetic nurses (28, 29 ), and an epidemiologic study of medical staffs exposed to anesthetic gases with special emphasis on detection of fertility and gravidity derangement (to be published).

\section{MATERIAL AND METHODS}

Air samples were collected in the work areas of anesthetic and surgical nurses during halothane anesthesia. "Mobile" samplers worn by the staff collected ambient air continuously from each bearer's respiratory zone, and "stationary" samplers collected air from sampling points near the work zones, but outside the actual respiratory zones, of the operating room personnel.

The sampling equipment consisted of a 30-ml glass syringe whose piston was withdrawn at a constant rate by a batterypowered electric motor. The open end of a copper capillary tube attached to the syringe was placed in the measurement zone. The mobile equipment was carried by the staff, i.e., anesthetic and surgical nurses, during their work. The mouth of the capillary tube was placed $5-10 \mathrm{~cm}$ from the bearer's nostrils.

Whenever possible, the exposure conditions of the staff were monitored throughout entire work shifts. In order to study the course of exposure during the actual periods of anesthesia, we changed the glass syringes in both the mobile and stationary equipment as close to the initiation and conclusion of anesthesia as the surgical and anesthesiological conditions permitted. This report describes the course of exposure during ongoing anesthesia.

Using the method described, we studied exposure conditions during the administration of halothane in 37 separate routine operations performed in nine operating departments at six major hospitals in the Stockholm and Uppsala areas. A total of 310 air samples from operating rooms and anesthetic induction rooms were collected during the administration of the anesthetic. One hundred and sixty-two of these samples were taken with mobile samplers in the respiratory zones of anesthetic and surgical nurses, and 148 samples were taken with stationary samplers in the vicinity of the work zones. The duration of sampling lasted from 5 to $58 \mathrm{~min}$ and varied from 20 to $40 \mathrm{~min}$ for $80 \%$ of the samples (246 of 310). All samples were time-weighted according to the formula $\left(\Sigma \mathrm{C}_{1} \mathrm{t}_{1}\right) / \mathrm{t} \quad\left[\mathrm{t}_{1}=\right.$ sampling duration (min) for air sample with concentration $\mathrm{C}_{\mathbf{1}}$ (ppm); $\mathrm{t}=$ period for time-weighting (min)], and the time-weighted concentrations of halothane and ethanol during the administration of the anesthetic were calculated.

In addition to the samples described, instantaneous samples were taken at various measuring points in conjunction with situations and work phases which could be suspected of giving rise to heavy exposure to anesthetic gases. Samples of end-expired air were taken from the anesthetic and surgical nurses, according to a given schedule, for the analysis of halothane and ethanol concentrations.

The investigation was supplemented with laboratory exposure trials in which a volunteer inhaled air, supplied by a tube and breathing valve, containing a known and constant concentration of halothane (32 ppm) or ethanol (58 ppm). The content of halothane and ethanol, respectively, in the end-expired air was examined every second to third minute during exposure, and frequent controls were made for more than $1 \mathrm{~h}$ after the termination of exposure.

Immediately after collection the samples were assayed for halothane $\left(\mathrm{CF}_{3}\right.$ $\mathrm{CHClBr})$ and ethanol $\left(\mathrm{C}_{2} \mathrm{H}_{5} \mathrm{OH}\right)$ with a gas chromatograph (AID, model 511) fitted with a flame ionization detector. The stainless steel column was $2 \mathrm{~m}$ long and $2.2 \mathrm{~mm}$ in diameter. It was packed with $2 \%$ Fractronil II (Merck) on 80-100 mesh Chromosorb G (Johns-Manville Co.). The oven temperature was $80^{\circ} \mathrm{C}$. Nitrogen flowing at $20 \mathrm{ml} / \mathrm{min}$ was used as the carrier gas. The sample volume was $1 \mathrm{ml}$. The gas standards for halothane and ethanol were prepared on the site in a glass flask whose design and operation are shown in fig. 1 . With the equipment 


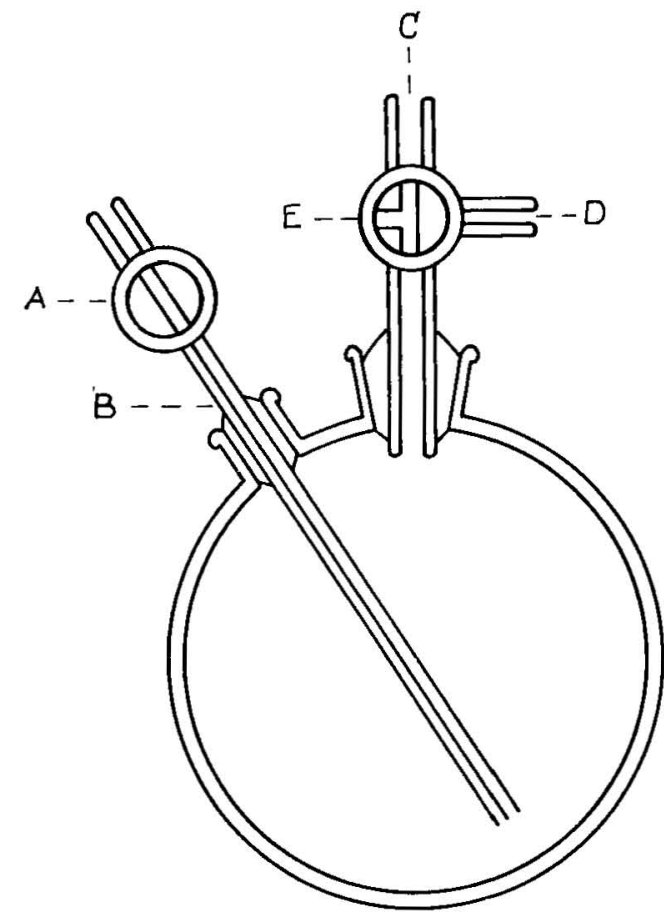

Fig. 1. Glass flask for the production of gas standard: The flask, whose volume had been carefully measured, is evaculated at D with the aid of a vacuum pump. The desired amount of standard (halothane or ethanol) is injected into the flask via capillary tube $B$ after cock $A$ is opened and cock $E$ is closed. The gas standard is removed at $\mathbf{C}$ after the establishment of equilibrium.

used, the limit of detection is about 0.2 ppm for halothane and about $0.5 \mathrm{ppm}$ for ethanol.

\section{RESULTS}

Table 1 shows exposure conditions in the different operating departments studied. Exposure varied widely, but the ethanol level in the operating rooms was usually higher than the halothane level during surgery.

The time-weighted halothane concentration measured with mobile equipment was nearly three times higher in the respiratory zone of the anesthetic nurses than in that of the surgical nurses. In the work zones of the anesthetic nurses - but not in those of the surgical nurses - a far higher level of halothane was detected in the samples collected with the mobile equipment than in those collected with the stationary equipment. Moreover, there was a greater spread in the halothane concentrations in instantaneous samples taken from the work zones of the anesthetic nurses than in corresponding samples taken from the work zones of the surgical nurses. The highest instantaneous values recorded for halothane $(340 \mathrm{ppm}$ and 23.5 ppm in the work zones of the anesthetic and surgical nurses, respectively) were both recorded in a department for pediatric surgery during anesthesia administered via a face mask without rebreathing.

End-expired air samples were taken simultaneously from the anesthetic and surgical nurses on 35 occasions. There was a good rank-order correlation between the halothane levels in both categories of nurses $\left(r_{\mathrm{s}}=0.85 ; r_{\mathrm{s}}=\right.$ Spearman's rank-order correlation coefficient), i.e., when the anesthetic nurse had a high halothane content in her end-expired air in relation to other anesthetic nurses, the surgical nurse had a high halothane concentration in her end-expired air in relation to other surgical nurses. In $86 \%$ of the cases ( 30 out of 35 ) the halothane concentration was the highest in the end-expired air of the anesthetic nurses. It was highest in the surgical nurses in only $3 \%$ ( 1 out of 35 ) and equally high in the remaining $11 \%$ (4 out of 35 ). The highest halothane level measured in end-expired air was $9.8 \mathrm{ppm}$ for anesthetic nurses and $4.8 \mathrm{ppm}$ for surgical nurses. These peak values were recorded during one and the same operation performed under anesthesia, with intubation and without rebreathing, in a department of pediatric surgery.

The time-weighted exposure to ethanol was similar for anesthetic and surgical nurses. There was consistent agreement between the ethanol levels in the corresponding air samples collected by mobile and stationary samplers. The highest ethanol concentrations recorded in endexpired air amounted to 12.3 and $14 \mathrm{ppm}$ in anesthetic and surgical nurses, respectively. These peak values were both recorded during the same operation in which also the highest instantaneous levels of 256 and $316 \mathrm{ppm}$ were recorded in the work zones of the anesthetic and surgical staff. The similarity of ethanol exposure 


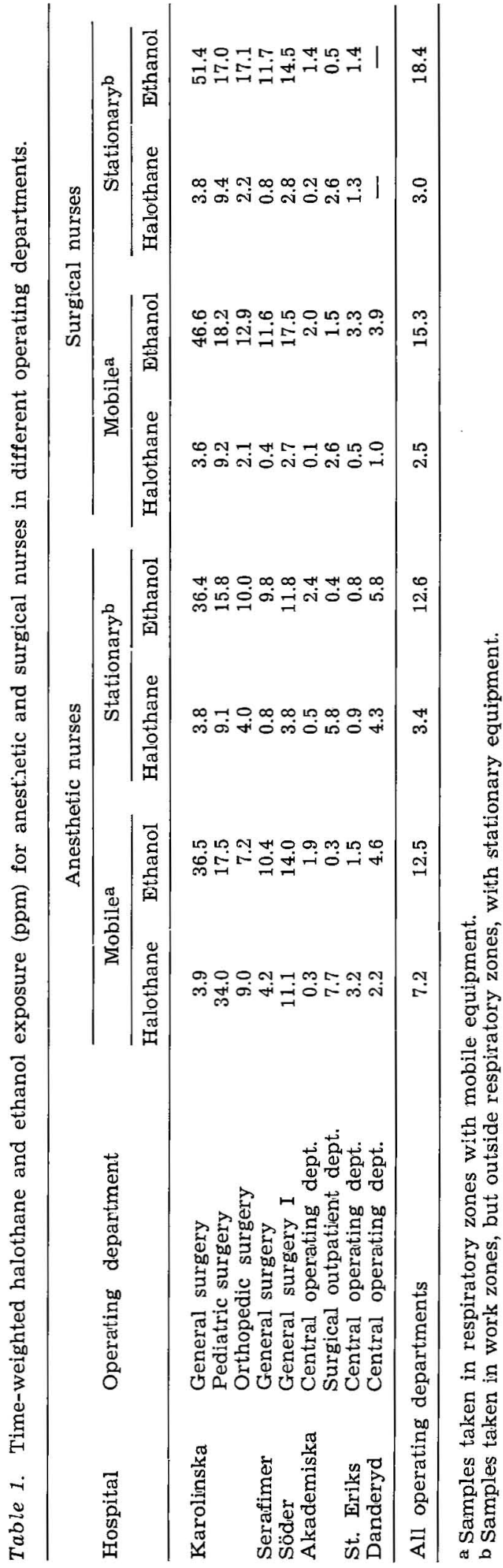

for both nurse categories was confirmed by the finding that ethanol levels in 35 pairs of end-expired air samples taken from anesthetic and surgical nurses working in parallel were highest in the anesthetic nurses in $37 \%$ (13 out of 35 ) of the paired comparisons, in the surgical nurses in $43 \%$ (15 out of 35 ), and equally great in the remaining $20 \%$ (7 out of 35 ).

In eight cases end-expired air samples were taken in conjunction with the conclusion of anesthesia and 17-78 min: thereafter. Following this "airing" time, which averaged about $40 \mathrm{~min}$, the mean value for the halothane content had dropped from 0.8 to $0.4 \mathrm{ppm}$, whereas the mean value for the ethanol content had risen from 0.4 to $2.3 \mathrm{ppm}$. Thus ethanol exposure was significant also after the conclusion of anesthesia and was not restricted to the anesthetic and surgical phases.

Tables 2 and 3 show that the method used for administering anesthesia affects the exposure of anesthetic nurses. The administration of volatile anesthetics via a face mask produced heavier exposure than administration via a tracheal tube. Non-rebreathing anesthetic systems resulted in greater exposure of the anesthetic staff than systems with partial rebreathing. Moreover, exposure tended to be greater when the patient breathed spontaneously than when his respiration was controlled. These differences were more striking in the respiratory zone of anesthetic nurses than in the area immediately outside this zone.

Ethanol exposure did not display such a regular pattern. However, the ethanol concentrations in the corresponding samples taken from mobile and stationary samplers were always on about the same level. This finding suggests that ethanol in the work zones of the operating staff was rather well-mixed with the room air.

In tables 4 and 5 exposure to halothane and ethanol is related to the standard of general ventilation in the operating rooms according to a personal communication from L. Olander. The standard of general ventilation had no decisive effect on the concentration of halothane in the respiratory zones of the operating staff when the anesthetic was administered via a face 
Table 6: The effect of local exhaust, close to the pop-off valve of the anesthetic machine, on the airborne concentrations (ppm) of halothane and ethanol.

A. Akademiska Hospital, Central Operating Department. (General ventilation system in operation)

\begin{tabular}{|c|c|c|c|c|c|c|c|c|}
\hline \multirow{3}{*}{ Local exhaust } & \multicolumn{4}{|c|}{ Anesthetic nurses } & \multicolumn{4}{|c|}{ Surgical nurses } \\
\hline & \multicolumn{2}{|c|}{ Mobile } & \multicolumn{2}{|c|}{ Stationary } & \multicolumn{2}{|c|}{ Mobile } & \multicolumn{2}{|c|}{ Stationary } \\
\hline & $\begin{array}{l}\text { Halo- } \\
\text { thane }\end{array}$ & Ethanol & $\begin{array}{l}\text { Halo- } \\
\text { thane }\end{array}$ & Ethanol & $\begin{array}{l}\text { Halo- } \\
\text { thane }\end{array}$ & Ethanol & $\begin{array}{l}\text { Halo- } \\
\text { thane }\end{array}$ & Ethanol \\
\hline On & 0.1 & 1.7 & 0.2 & 1.8 & 0.0 & 2.0 & 0.0 & 1.5 \\
\hline Off & 0.8 & 2.2 & 1.0 & 3.6 & 0.5 & 1.9 & 0.5 & 1.4 \\
\hline Total & 0.4 & 1.9 & 0.5 & 2.5 & 0.1 & 2.0 & 0.2 & 1.5 \\
\hline
\end{tabular}

B. Karolinska Hospital, Department of Pediatric Surgery.

\begin{tabular}{|c|c|c|c|c|c|c|c|c|c|}
\hline \multirow{3}{*}{$\begin{array}{l}\text { Local } \\
\text { exhaust }\end{array}$} & \multirow{3}{*}{$\begin{array}{l}\text { General } \\
\text { venti- } \\
\text { lation }\end{array}$} & \multicolumn{4}{|c|}{ Anesthetic nurses } & \multicolumn{4}{|c|}{ Surgical nurses } \\
\hline & & \multicolumn{2}{|c|}{ Mobile } & \multicolumn{2}{|c|}{ Stationary } & \multicolumn{2}{|c|}{ Mobile } & \multicolumn{2}{|c|}{ Stationary } \\
\hline & & $\begin{array}{l}\text { Halo- } \\
\text { thane }\end{array}$ & Ethanol & $\begin{array}{l}\text { Halo- } \\
\text { thane }\end{array}$ & Ethanol & $\begin{array}{l}\text { Halo- } \\
\text { thane }\end{array}$ & Ethanol & $\begin{array}{l}\text { Halo- } \\
\text { thane }\end{array}$ & Ethanol \\
\hline On & Off & 36.5 & 28.5 & 15.6 & 28.4 & 12.5 & 24.8 & 12.7 & 24.8 \\
\hline Off & On & 31.1 & 4.8 & 3.2 & 4.1 & 5.0 & 9.7 & 5.1 & 7.0 \\
\hline Total & & 34.0 & 17.5 & 9.2 & 15.8 & 9.2 & 18.2 & 9.4 & 17.0 \\
\hline
\end{tabular}

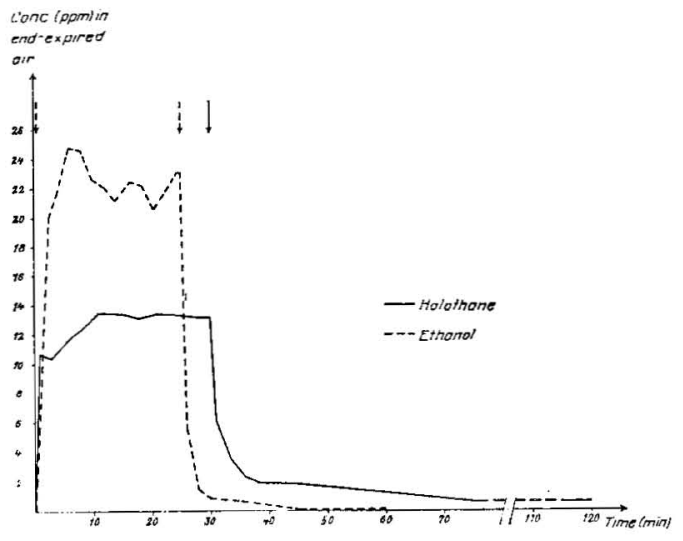

Fig. 2. Concentrations of ethanol and halothane in end-expired air during and after exposure to $58 \mathrm{ppm}$ of ethanol or $32 \mathrm{ppm}$ of halothane (exposure between the arrows).

of operating staff to anesthetic gases have been suspected for a long time $(21,36,48$, $67)$, efforts made to evacuate airborne anesthetics were primarily justified by a need to eliminate the risk of explosion (13, 24) and unpleasant odor (42). In the past decade the development of more efficient ventilation systems for operating rooms was given great impetus by discoveries of an increased incidence of pregnancy complications $(5,15,16,37,38,53,65)$ and malignant diseases $(12,20)$ in occupational groups exposed to anesthetic gases.

Operating staffs are exposed not only to anesthetic gases but also to ethanol, a volatile component in the disinfectants used. Ethanol vapor is more evenly distributed in the operating room than anesthetic gases. Therefore, exposure to ethanol is similar for both anesthetic and surgical personnel. This exposure is not merely limited to the anesthetic and surgical phases themselves, but can be considerable even after the conclusion of surgery. This is apparently because disinfectants containing ethanol are employed by both surgical and anesthetic personnel in the subsequent treatment of patients and the cleansing of instruments.

If it is assumed that about $60 \%$ of the ethanol inhaled is resorbed, a continuous $15 \mathrm{ppm}$ concentration of ethanol in alveolar air (an extreme value in the present 
study) corresponds to resorption of only about $25 \mathrm{mg}$ of ethanol per hour. Since an average adult can metabolize about $10 \mathrm{ml}$ (i.e., $8,000 \mathrm{mg}$ ) of ethanol per hour (52), the exposure to ethanol cannot be regarded as critical for the operating staff. It is obvious that the small amounts of ethanol inhaled are rapidly eliminated due to the metabolic capacity of the body. However, ethanol should be regarded as an indicator of the presence of volatile disinfectant components, and their spread through the room atmosphere should be kept in mind when the ventilation of operating rooms is designed.

The elimination of halothane is considerably slower than that of ethanol. After an initially rapid elimination, low residual concentrations are demonstrable in end-expired air for a long time. This finding is in agreement with the results reported by Whitcher et al. (68), who found low residual concentrations in many individuals $16 \mathrm{~h}$ after exposure. This slow decay is not specific for halothane, but has also been demonstrated for, e.g., methoxyflurane (18).

The fact that the exposure of operating staffs to anesthetic gases is influenced by the anesthetic method has been noted earlier $(6,55)$. The dissemination of anesthetic gases is easier to control when the gases are supplied via a tracheal tube instead of a face mask, when the patient's respiration is controlled rather than spontaneous, and when rebreathing or partial rebreathing anesthetic systems are employed instead of non-rebreathing systems. Thus in the anesthetic routines it is reasonable also to take into consideration occupational hygiene as, e.g., Feychting et al. (26) and Mostert (44) have emphasized.

The effective ventilation of airborne pollutants in an operating room calls for good general ventilation in conjunction with local exhaust close to the sources of anesthetic gas leakage. General ventilation mainly affects the concentration of substances well-mixed with room air. Thus good general ventilation is a requirement for the elimination of, e.g., volatile disinfectant components, such as ethanol, and anesthetic vapor which has spread beyond the actual work zones. On the other hand, general ventilation only has a limited effect on the concentration of anesthetic gas close to the source of leakage near which the respiratory zone of anesthetic staff is located.

A number of technical systems have been described which facilitate the ventilation of anesthetic gases from sources of leakage $(4,8,9,11,13,14,17,23,25,36,40$, $41,43,48,50,54,62,70)$. Diverting the anesthetic gases via a tube to the floor fails to produce any satisfactory reduction in the exposure of staff $(10,31)$. Anesthetic gases should be extracted from the operating room so that there is no risk of recirculation or translocation to adjacent rooms (64).

Certain anesthetic gases can be filtered out of recirculated air with an activated charcoal filter $(2,24,33,42,55,60,61,66)$. However the view that such a filter, "should prove more satisfactory than merely venting anaesthetic vapours to the exterior," (22) is open to doubt. These filters have a limited capacity, and even the most scrupulously maintained filter system is incapable of blocking the passage of nitrous oxide, which is regularly used in high concentrations in conjunction with other anesthetic gases. Therefore, filter systems should be regarded as supplements to direct evacuation systems, but they are no adequate substitute.

Efficient venting of anesthetic gases right at the source of leakage generally results in a very significant reduction in the concentration of airborne anesthetics $(6,11,18,49,68)$. However, a local exhaust system obviously does not eliminate the need for general ventilation. If local exhaust systems are to achieve the optimum effect, the evacuation nozzles must be correctly designed and located, and they must produce suction approporiate to other ventilation. In addition, the venting system must not change the function of the anesthetic machine. Staff exposure to anesthetic gases could even increase when ventilation is turned on, if the ventilation is not properly designed (63).

In addition to nitrous oxide, halothane has been the most widely used anesthetic for more than a decade. This circumstance, plus the fact that most studies of airborne anesthetics in operating rooms have been performed in conjunction with halothane anesthesia, has led to a tendency to link 
the risks presented by chronic exposure to anesthetics to the substance halothane. This tendency could trigger increased interest in replacing halothane with other volatile anesthetics in the belief that occupational risks would thereby be reduced. However, halothane should only be regarded as a substance indicating the manner in which anesthetic gases can spread into the work zones of the operating staff.

All anesthetic gases should be treated with the same respect. There is no evidence that occupational risks are linked, e.g., to the halogen component in modern volatile anesthetics. Animal experiments have shown that it is possible to induce teratogenic effects not only with halogenated substances such as halothane $(7,35,58,69)$ and methoxyflurane (58), but also with nitrous oxide $(19,27,51,59)$, diethyl ether (57) and cyclopropane (1). Vaismann (65) found a very high incidence of pregnancy complications among female Russian anesthesiologists who had mainly been exposed to diethyl ether at the time of his study.

Special safety regulations have recently been introduced in Sweden in order to reduce the exposure of medical staff to anesthetic gases (3). Since measurable levels of anesthetic gases have been found even outside operating rooms $(49,64)$, the new regulations make it necessary for general ventilation to meet certain minimum requirements not only in operating rooms but also in anesthetic induction rooms and recovery rooms. Operating rooms and anesthetic induction rooms must also be supplied with equipment making possible local exhaust of anesthetic gases. In operating rooms satisfying the ventilation standards set, the time-weighted exposure of the medical staff should be far less than $250 \mathrm{ppm}$ for nitrous oxide and $5 \mathrm{ppm}$ for halothane under normal conditions (47).

\section{ACKNOWLEDGMENTS}

Thanks are due to Ms. May Hultengren for her technical assistance.

The study was financed by grants from the National Board of Occupational Safety and Health, Sweden.

\section{REFERENCES}

1. ANDERSEN, N. B. The teratogenicity of cyclopropane in the chicken. Anesthesiology 29 (1968) 113-122.

2. AONO, M., SANO, M., SAWA, T., HORI, T. and IZEKONO, E. [Exhausted anesthetic gases and the health of anesthetists]. Jpn. j. anesthesiol. 21 (1972) 282-288. (English summary)

3. ARBETARSKYDDSSTYRELSEN. Narkosanvisningar (Arbetarskyddsstyrelsens anvisningar no 102). Stockholm 1974.

4. ASKROG, V. F. [Exspiratory valve with gas collecting canal]. Nord. med. 83 (1970) 811-812. (English summary)

5. ASKROG, V. and HARVALD, B. [Teratogenic effects of inhalation anaesthetics]. Nord. med. 83 (1970) 498-500. (English summary)

6. ASKROG, V. and PETERSEN, R. [Contamination of operating theatres from inhalation anaesthetics and ionizing radiation]. Nord. med. 83 (1970) 501-504. (English summary)

7. BASFORD, A. B. and FINK, B. R. Teratogenicity of halothane in rats. Anesthesiology 29 (1968) 173-174.

8. BERNER, O. A volume and pressure controlling spill valve equipped for removal of excess anesthetic gas. Acta anaesthesiol. scand. 16 (1972) 252-258.

9. BEST, D. W. S. A simple inexpensive system for the removal of excess anaesthetic vapours. Can. anaesth. soc. j. 18: (1971) $333-338$.

10. BRENDSTRUP, A. [Contamination of air in operating theatres during halothane anaesthesia]. Ugeskr. laeg. 134 (1972) 388390. (English summary)

11. BRUCE, D. L. A simple way to vent anesthetic gases. Anesth. analg. (Cleve) 52 (1973) 595-598.

12. BRUCE, D. L., EIDE, K. A., LINDE, H. W. and ECKENHOFF, J. E. Causes of death among anesthesiologists: A 20-year survey. Anesthesiology 29 (1968) 565-569.

13. BULLOUGH, J. Anesthetic explosions, prevention by withdrawal method. Lancet 1 (1954) $798-801$.

14. CAMERON, H. Pollution control in the operating room: A simple device for the removal of expired anaesthesia vapours. Can. anaesth. soc. j. 17 (1970) 535-539.

15. COHEN, E. N., BELLVILLE, J. W. and BROWN, B. W. JR. Anesthesia, pregnancy, and miscarriage: A study of operating room nurses and anesthetists. Anesthesiology 35 (1971) 343-347.

16. COHEN, E. N., BROWN, B. W., BRUCE, D. L., CASCORBI, H. F., CORBETT, T. H., JONES, T. W. and WHITCHER, C. E. Occupational disease among operating room personnel: A national study. Anesthesiology 41 (1974) 321-340.

17. CORBETT, T. H. The gas trap: A device to minimize chronic exposure to anesthetic gases. Anesthesiology 31 (1969) 464. 
18. CORBETT, T. H. and BALL, G. L. Chronic exposure to methoxyflurane: A possible occupational hazard to anesthesiologists. Anesthesiology 34 (1971) 532-537.

19. CORBETT, T. H., CORNELL, R. G., ENDRES, J. L. and MILLARD, R. I. Effects of low concentrations of nitrous oxide on rat pregnancy. Anesthesiology 39 (1973) 299301.

20. CORBETT, T. H., CORNELL, R. G., LIEDING, K. and ENDRES, J. L. Incidence of cancer among Michigan nurse-anesthetists. Anesthesiology 38 (1973) 260-263.

21. DAVIS, D. A. The operating room: An unhealthy environment? In: D. A. DAVIS (ed.), Historical vignettes of anesthesia (vol. 2). F. A. Davis Co., Philadephia, Pa. 1968 , pp. $42-45$.

22. EDITORIAL. Anesthetic contamination. Br. med. $j .1$ (1973) 693-694.

23. ENDERBY, G. E. H. Gas exhaust valve Anaesthesia 27 (1972) 334-337.

24. EPSTEIN, H. G. Removal of ether vapour during anaesthesia. Lancet 1 (1944) 114116.

25. EVANS-PROSSER, C. D. G. A circuit to reduce the inhalation of gases by anaesthetists. Br. j. anaesth. 44 (1972) 412 .

26. FEYCHTING, H., KULLING, P. and SETTERGREN, G. Arterial carbon dioxide tension during anaesthesia in children. IVth European congress of anaesthesiology, Madrid Sept., 1974. Excerpta medica, international congress series no. 330. Abstract no. 269.

27. FINK, B. R., SHEPARD, T. H. and BLANDAU, R. J. Teratogenic activity of nitrous oxide. Nature 214 (1967) 146-148.

28. GAMBERALE, F. and SVENSSON, G. The effect of anesthetic gases on the psychomotor and perceptual functions of anesthetic nurses. Scand. j. work environ. \& health 11 (1974) 108-113.

29. GAMBERALE, F., SVENSSON, G. and ANDERSSON, B. Narkosgasers effekt på psykomotoriska funktioner hos narkossköterskor. (Arbete och hälsa no. 5.) Arbetarskyddsverket, Stockholm 1973. $13 \mathrm{p}$.

30. GÖTELL, P. and SUNDELL, L. Anaesthesists' exposure to halothane. Lancet 2 (1972) 424.

31. GOSTOMZYK, J. G., EISELE, G. and AHNEFELD, F. W. Chronische Narkosegasbelastung des Anaesthesiepersonals im Operationssaal. Anaesthesist 22 (1973) 469 $-474$

32. HALLEN, B., EHRNER-SAMUEL, H. and THOMASON, M. Measurements of halothane in the atmosphere of an operating theatre and in expired air and blood of the personnel during routine anaesthetic work. Acta anaesthesiol. scand. 14 (1970) 17-27.

33. HAWKINS, T. J. Atmospheric pollution in operating theatres: A review and a report on the use of reusable activated charcoal canisters. Anaesthesia 28 (1973) 490-500.

34. HIRSCH, J. and KAPPUS, A. L. Uber die Mengen des Narkoseäthers in der Luft von Operationssälen. Z. hyg. 110 (1929) 391398.
35. JACOBSEN, L., KRUSE, V. and TRÄFF, B. [Experimental studies on the possible teratogenic effect of halothane]. Nord. med. 84 (1970) 941-944. (English summary)

36. KELLING, G. Utber die Beseitigung der Narkosedämpfe aus dem Operationssaale. Zentralbl. Chir. 45 (1918) 602-606.

37. KNILL-JONES, R. P., RODRIGUES, L. V., MOIR, D. D. and SPENCE, A. A. Anaesthetic practice and pregnancy. Controlled survey of women anaesthetists in the United Kingdom. Lancet 1 (1972) 1326-1328.

38. LENCZ, L., NEMES, C. S. and BERTA, L. Psychische Belastungen und Morbidität der Anaesthesisten. IIIrd European congress of anaesthesiology, Prague 1970. Abstract no. $63 / 02$.

39. LINDE, H. W. and BRUCE, D. L. Occupational exposure of anesthetists to halothane, nitrous oxide and radiation. Anesthesiology 30 (1969) 363-368.

40. LUNDBERG, S. and FRIBERG, A. Evakuering av narkosgaser - ett utbyggt system. Medicinsk Riksstämma, Stockholm 1968. Sammanfattningar, pp. 77-78.

41. MC INNES, I. C. and GOLDWATER, H. L. Gas removal systems for commonly used circuits. Anaesthesia 27 (1972) 340-347.

42. MC INTYRE, J. W. R. and RUSSEL, J. C. Removal of halothane and methoxyflurane from waste anaesthetic vapours. Can. anaesth. soc. j. 14 (1967) 333-339.

43. MARRESE, R. A. A safe method for discharging anesthetic gases. Anesthesiology 31 (1969) 371-372.

44. MOSTERT, J. W. Closed-circuit protection for anaesthetists. Lancet 2 (1972) 758-759.

45. NIKKI, P., PFÄFFLI, P. and AHLMAN, K. End-tidal and blood halothane and nitrous oxide in surgical personnel. Lancet 2 (1972) $490-491$.

46. NIKKI, P., PFÄFFLI, P., AHLMAN, K. and RALLI, R. Chronic exposure to anaesthetic gases in the operating theatre and recovery room. Ann. clin. res. 4 (1972) $266-272$.

47. OLANDER, L. Operationsrums ventilationsstandard. Lustgaskoncentrationer $i$ operationsrum. (Arbete och hälsa no. 3) Arbetarskyddsverket, Stockholm 1974. $41 \mathrm{p}$.

48. PERTHES, G. Schutz der am Operationstisch Beschäftigten vor Schädigung durch die Narkosegase. Zentralbl. Chir. 52 (1925) 852-854.

49. PFÄFFLI, P., NIKKI, P. and AHLMAN, K. Halothane and nitrous oxide in end-tidal air and venous blood of surgical personnel. Ann clin. res. 4 (1972) 273-277.

50. PRICE, M. and MC KEEVER, R. Anaesthetic antipollution device. Can. anaesth. soc. j. 17 (1970) 540 .

51. RECTOR, G. H. M. and EASTWOOD, D. W The effects of an atmosphere of nitrous oxide and oxygen on the incubating chick. Anesthesiology 25 (1964) 109.

52. RITCHIE, J. M. The aliphatic alcohols. In: L. S. GOODMAN, and A. GILMAN (eds.), The pharmacological basis of therapeutics (4th ed.). MacMillan Co., London and Toronto 1970 , pp. 135-150. 
53. ROSENBERG, P. and KIRVES, A. Miscarriage among operating theatre staff. Acta. anaesthesiol. scand. (1973): suppl. 53, $37-42$.

54. SCHNELLE, N. and NELSON, D. A new device collecting and disposing of exhaust gases from the anesthesia machine. Anesth. analg. (Cleve) 48 (1969) 744-747.

55. SCHULZE, H. H., KÄSTNER, D. and LANGE, P. Zur Frage der chronischen Toxicität von Halothankonzentrationen in der Operationssaalluft. Anaesthesist 18 (1969) 378-381.

56. SCHULZE, H. H., KÄSTNER, D. and LANGE, P. Zur Frage der chronischen Toxizität von Halothankonzentrationen in der Operationssaalluft und im Blut des Anaesthesisten. In: J. HODER, J. JEDLICKA and J. POKORNY (eds.), Advances in anaesthesiology and resuscitation (vol. 2). Avicenum - Czechoslovak Medical Press, Prague 1972, pp. 1582-1583.

57. SMITH, B. E., GAUB, M. L. and LEHRER S. B. Teratogenic effects of diethyl ethei in the chick embryo. In: B. R. FINK (ed.), Toxicity of anesthetics. Williams and Wilkins Co., Baltimore, Md. 1968, pp. 269-278.

58. SMITH, B. E., GAUB, M. L. and MOYA, F. Investigations into the teratogenic effects of anesthetic agents: The fluorinated agents. Anesthesiology 26 (1965) 260-261.

59. SMITH, B. E., GAUB, M. L. and MOYA, F. Teratogenic effects of anesthetic agents: Nitrous oxide. Anesth. analg. (Cleve) 44 (1965) $726-732$.

60. SPIERDIJK, J. and REGJER, V. Dangers of chronic exposure to inhalation anaesthetics. Preventive measures. Acta. anaesthesiol. belg. 24 (1973) 115-127.

61. STÅLHAMMAR, D., PETTERSSON, G., RAMHULT, T. and VALLMO, L. Ett sätt att reducera utsläppet av inhalationsnarkosmedel från narkosapparater. Medicinsk. Riksstämma, Stockholm 1968. Sammanfattningar, p. 79 .

62. STEWARD, D. J. An anti-pollution device for use with the Jackson-Rees modification of Ayre's T-piece. Can. anaesth. soc. j. 19 (1972) $670-671$.

63. STRUNIN, L., STRUNIN, J. M. and MALLIOS, C. C. Atmospheric pollution with halothane during outpatient dental anaesthesia. Br. med. j. 4 (1973) $459-460$.

64. USUBIAGA, L., ALDRETE, J. A. and FISEROVA-BERGEROVA, V. Influence of gas flows and operating room ventilation on the daily exposure of anesthetists to halothane. Anesth. analg. (Cleve) 51 (1972) 968-971.

65. VAISMANN, A. I. [Work in surgical theatres and its influence on the health of anaesthesiologists]. Eksp. Khir. Anestheziol. 12: 3 (1967) 44-49. (Russian)

66. VAUGHAN, R. S., MAPLESON, W. W. and MUSHIN, W. W. Prevention of pollution of operating theatres with halothane vapour by adsorption with activated charcoal. Br. med. j. 1 (1973) 727-729.

67. WERTHMANN, H. Beitrag zur chronischen Atherintoxikation der Chirurgen. Beitr. Klin. Chir. 178 (1949) 149-156.

68. WHITCHER, C. E., COHEN, E. N. and TRUDELL, J. R. Chronic exposure to anesthetic gases in the operating room. Anesthesiology 35 (1971) 348-353.

69. WITTMANN, R., DOENICKE, A., HEINRICH, H. and PAUSCH, H. Die abortive Wirkung von Halothane. Anaesthesist 23 (1974) 30 -35.

70. YEAKEL, A. E. A device for eliminating overflow anesthetic gases from anesthetizing locations. Anesthesiology 32 (1970) 280.

Received for publication: 1975-09-01 